\title{
Syntheses, Characterization and X-ray Crystal Structure of Polymeric Heteronuclear Oxo-bridged Fe/Na Assembled with Salen-type Schiff Base and Dicyanamide
}

\author{
Popa Haba ${ }^{1}$, Mouhamadou Moustapha Sow ${ }^{2}$, Mamour Sarr ${ }^{1}$, Ibrahima Elhadji Thiam ${ }^{1}$, \\ Mahy Diaw ${ }^{2}$, Mohamed Lamine Gaye ${ }^{1, *}$ \\ ${ }^{1}$ Organic Coordination Chemistry Laboratory, Department of Chemistry, Faculty of Science and Technology, Cheikh Anta DIOP University, \\ Dakar, Senegal \\ ${ }^{2}$ Coordination Chemistry Laboratory, Department of Chemistry, UFR SATIC, Alioune DIOP University, Bambey, Senegal
}

Email address:

mohamedl.gaye@ucad.edu.sn (M. L. Gaye)

${ }^{*}$ Corresponding author

\section{To cite this article:}

Popa Haba, Mouhamadou Moustapha Sow, Mamour Sarr, Ibrahima Elhadji Thiam, Mahy Diaw, Mohamed Lamine Gaye. Syntheses, Characterization and X-ray Crystal Structure of Polymeric Heteronuclear Oxo-bridged Fe/Na Assembled with Salen-type Schiff Base and Dicyanamide. Science Journal of Chemistry. Vol. 8, No. 2, 2020, pp. 20-27. doi: 10.11648/j.sjc.20200802.11

Received: March 6, 2020; Accepted: March 23, 2020; Published: April 17, 2020

\begin{abstract}
Reaction of $\mathrm{FeCl}_{2} \cdot 4 \mathrm{H}_{2} \mathrm{O}$ with 2-(-(2-(-2-hydroxy-3-methoxybenzylideneamino)phenylimino)methyl)-6methoxyphenol $\left(\mathrm{H}_{2} \mathrm{~L}\right)$ gives the metalloligand $[\mathrm{Fe}(\mathrm{L})] \cdot\left(\mathrm{H}_{2} \mathrm{O}\right)$ (1). Reaction of metalloligand (1) with three fold of sodium dicyanamide $\mathrm{Na}\left[\mathrm{N}(\mathrm{CN})_{2}\right]$ gives the new tetranuclear compound $\left.\left[\left\{\mathrm{Fe}^{\mathrm{II}} \mathrm{Na}(\mathrm{L})(\mathrm{EtOH})\left(\mathrm{HN}(\mathrm{CN})_{2}\right)\right\}(\mu-\mathrm{O})\left\{\mathrm{Fe}^{\mathrm{III}} \mathrm{Na}^{\mathrm{I}}(\mathrm{L})\left(\mathrm{NO}_{3}\right)\right]\right\}\right]_{\mathrm{n}}(2)$ in which one of the two irons is oxidized to +3 . Suitable crystals of (2) were grown by slow evaporation of ethanol solution during two weeks. The metalloligand (1) and the tetranuclear (2) complexes are characterized by IR and physical measurement. Spectroscopic evidence indicated that the Schiff base $\mathrm{H}_{2} \mathrm{~L}$ behave an $\mathrm{N}_{2} \mathrm{O}_{2} \mathrm{O}_{2}{ }_{2}$ coordination tetradentate ligand. The structure of (2) was elucidated by X-ray diffraction analysis. The asymmetric unit of the compound contains two dideprotonated ligand molecules, two iron ions, one hexacoordinated sodium ion, one heptacoordinated sodium ion, one bidentate nitrate group, one monodentate dicyanamide unit, one coordinated ethanol molecule and an $\mathrm{O}^{2-}$ ion which acts as a bridge between the $\mathrm{Fe}^{\mathrm{II}}$ and the $\mathrm{Fe}^{\mathrm{III}}$ of two entities: $\left[\mathrm{Fe}^{\mathrm{II}} \mathrm{Na}^{\mathrm{I}}(\mathrm{L})(\mathrm{EtOH})\left(\mathrm{HN}(\mathrm{CN})_{2}\right)\right]$ and $\left[\mathrm{Fe}^{\mathrm{III}} \mathrm{Na}^{\mathrm{I}}(\mathrm{L})\left(\mathrm{NO}_{3}\right)\right]$. Bridge $\mathrm{Fe}-\mathrm{O}(\mu)$ bond lengths are 1.7813(14) and 1.7856(13) $\AA$ and bridging angle $\mathrm{Fe}-\mathrm{O}-\mathrm{Fe}$ is $144.78(8)^{\circ}$. The second terminal cyano group of the dicyanamide link another molecule complex through the heptacoordinated $\mathrm{Na}^{\mathrm{I}}$ leading a polymeric structure. Intermolecular hydrogen bond connect the polymeric chains to develop a three dimensional structure.
\end{abstract}

Keywords: Iron, Metalloligand, O-vanillin, Sodium Dicyanamide

\section{Introduction}

Bi-compartmental Schiff bases are widely used in the design of homo-polynuclear and hetero-polynuclear complexes owing to their peculiar physicochemical properties [1-5]. This development results in the association of metal ions with different nature and ligands which can yield molecular entities with great interest in the fields of molecular magnetism [6-9], optics [10-12], biology [13], absorption [14], catalysis [15] and luminescence [16, 17]. Hetero-polynuclear complexes with $3 \mathrm{~d}$ transition metal and $4 \mathrm{f}$ lanthanide ions are largely reported in the literature [18-
20]. This field has also experienced a renaissance with the synthesis of new hetero-metallic compounds $3 d / n s$ very promising in much domains such as molecular magnetism [1, $2,5,21]$. In addition, the insertion of diamagnetic metal ions such as alkali ions and lanthanide ions can gave precious information on the relationship magneto-structural of these compounds [3, 22]. However, access to hetero-polynuclear polymers incorporating $n s$ ions and $3 d$ ions with different degrees of oxidation, ie. Sodium (I) and iron (II, III) is a challenge from a synthetic point of view [21, 22]. Systematically, hetero-polymetallic complexes can be obtained according to two different strategies. The self- 
assembly method is widely used to prepare $3 \mathrm{~d} / 4 \mathrm{f}$ complexes [4-7]. Indeed, many hetero-polynuclear complexes with remarkable properties have been obtained by the selfassembly method [8-10]. The metalloligand method, which consists to prepare a complex as a precursor [3, 23] for the second step of the reaction. This last method can be used to prepare discrete or infinite hetero-metallic complexes [11-13]. Our synthetic approach consists in using an iron(II)-based metalloligand $[\mathrm{Fe}(\mathrm{L})] .\left(\mathrm{H}_{2} \mathrm{O}\right)$ as precursor synthesized from the bi-compartmental Schiff ligand derived from o-vanillin $\left(\mathrm{H}_{2} \mathrm{~L}\right)$. In this article we report a hetero-polynuclear species $\left.\left[\left\{\mathrm{Fe}^{\mathrm{II}} \mathrm{Na}^{\mathrm{I}}(\mathrm{L})(\mathrm{EtOH})\left(\mathrm{HN}(\mathrm{CN})_{2}\right)\right\}(-\mathrm{O})\left\{\mathrm{Fe}^{\mathrm{III}} \mathrm{Na}^{\mathrm{I}}(\mathrm{L})\left(\mathrm{NO}_{3}\right)\right]\right\}\right]_{\mathrm{n}}$ (2) obtained using the metalloligand $[\mathrm{Fe}(\mathrm{L})] \cdot\left(\mathrm{H}_{2} \mathrm{O}\right)(1)$ and $\mathrm{Na}\left(\mathrm{N}(\mathrm{CN})_{2}\right)$ (Figure 1). The crystal structure and the physico-chemical properties are discussed.
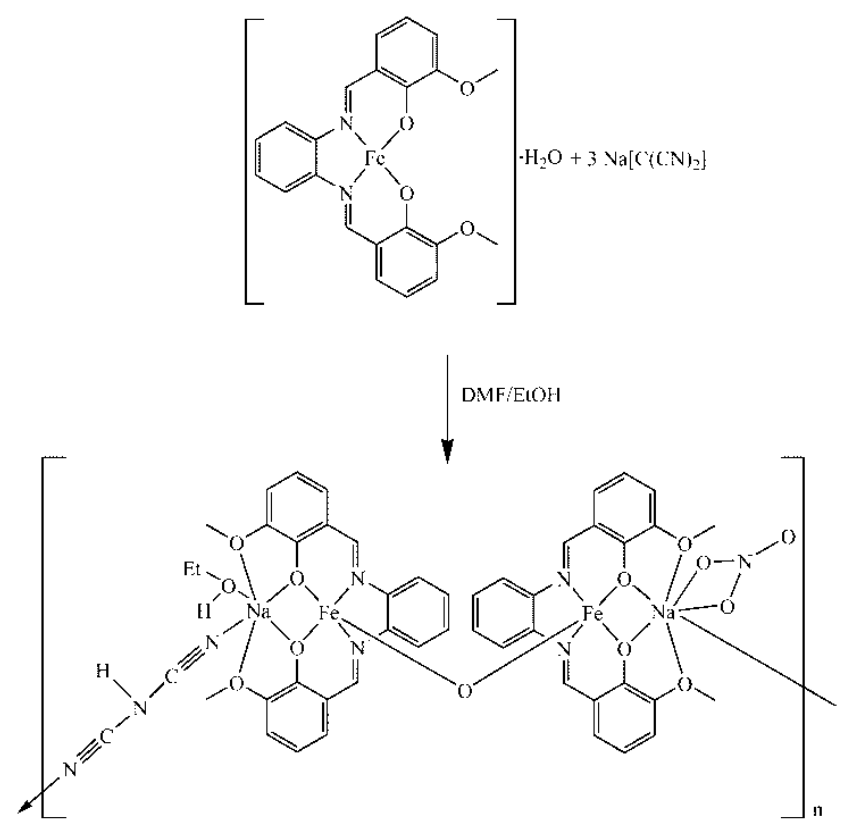

Figure 1. Chemical diagrams for $[\mathrm{Fe}(\mathrm{L})] \cdot\left(\mathrm{H}_{2} \mathrm{O}\right)$ (1) and $\left.\left[\left\{\mathrm{Fe}^{I I} \mathrm{Na} a^{I}(\mathrm{~L})(\mathrm{EtOH})\left(\mathrm{HN}(\mathrm{CN})_{2}\right)\right\}(-\mathrm{O})\left\{\mathrm{Fe}^{I I I} \mathrm{Na}^{I}(\mathrm{~L})\left(\mathrm{NO}_{3}\right)\right]\right\}\right]_{n}(2)$.

\section{Materials and Methods}

\subsection{General Information}

o-Vanillin and 1,3-diaminobenzene, iron chloride tetrahydrate, and sodium dicyanamide were purchased from Sigma-Aldrich and used as received without further purification. All solvents used were of reagent grade. The ligand $\left(\mathrm{H}_{2} \mathrm{~L}\right)$ was synthesized following the reported procedure [24]. Elemental analyses of $\mathrm{C}, \mathrm{H}$ and $\mathrm{N}$ were recorded on a VxRio EL Instrument. Infrared spectra were obtained on an FTIR Spectrum Two of Perkin Elmer spectrometer in the $4000-400 \mathrm{~cm}^{-1}$ region. The molar conductance of $1 \times 10^{-3} \mathrm{M}$ in DMSO solutions of the metal complexes was measured at $25{ }^{\circ} \mathrm{C}$ using a WTW LF-330 conductivity meter with a WTW conductivity cell. Room temperature magnetic susceptibilities of the powdered samples were measured using a Johnson Mattey scientific magnetic susceptibility balance (Calibrant: $\mathrm{Hg}[\mathrm{Co}(\mathrm{SCN}) 4]$ ).

\subsection{Synthesis and Characterization of (1) and (2)}

In a round bottomed flask, the ligand $\left(\mathrm{H}_{2} \mathrm{~L}\right)(10 \mathrm{mmol}$, $0.374 \mathrm{~g}$ ) was dissolved in $5 \mathrm{~mL}$ of acetonitrile. A solution of $\mathrm{FeCl}_{2} \cdot 4 \mathrm{H}_{2} \mathrm{O}(10 \mathrm{mmol}, 0.199 \mathrm{~g})$ in $5 \mathrm{~mL}$ of methanol was added. After two hours under reflux, the brown precipitate was recovered by filtration, washed with ether $(2 \times 10 \mathrm{~mL})$ and dried in air. The compound was formulated as [Fe(L)] $\left(\mathrm{H}_{2} \mathrm{O}\right)$. Yield: $80 \%$. Elemental Anal. Found (Calcd.) (\%): C, 58.92 (58.95); H, 4.48 (4.50); N, 6.22 (2.25). IR ( , $\left.\mathrm{cm}^{-1}\right):\left[\mathrm{v}(\mathrm{O}-\mathrm{H}) 3343, \quad\left(\mathrm{OH}_{2}\right) 851\right] ; 1627 \mathrm{v}(\mathrm{C}=\mathrm{N}), 1597$; $v(\mathrm{C}-\mathrm{OPh}), 1236 ; \mathrm{v}(\mathrm{C}-\mathrm{OMe}), 1201 . \wedge\left(\mathrm{S}^{\wedge} \mathrm{cm}^{2} \cdot \mathrm{mol}^{-1}\right): 7 . \quad$ eff (MB): 4.8 .

To a solution of $[\mathrm{Fe}(\mathrm{L})] \cdot \mathrm{H}_{2} \mathrm{O}(1)(1 \mathrm{mmol}, 0.43 \mathrm{~g})$ in $5 \mathrm{~mL}$ of DMF was added a solution of $\mathrm{Na}\left[\mathrm{N}(\mathrm{CN})_{2}\right]$ ( $3 \mathrm{mmol}, 0.261$ $\mathrm{g})$ in $5 \mathrm{~mL}$ of ethanol. The mixture was refluxed during two hours. On cooling red precipitate, which appears, was recovered by filtration. The filtrate was left for slow evaporation. On standing for two weeks, red crystals of (2) suitable for X-ray diffraction were isolated. Yield: 50\%. Elemental Anal. Found (Calcd.) (\%): C, 52.51 (52.53); H, 3.92 (3.95); N, $10.19(10.21)$. IR $\left(\quad, \mathrm{cm}^{-1}\right): v(\mathrm{C}=\mathrm{N})=1599$; $v(\mathrm{C}-\mathrm{OPh})=1241 ; \mathrm{v}(\mathrm{C}-\mathrm{OMe}) 1197 ; \mathrm{v}(\mathrm{C} \equiv \mathrm{N}): 2250,2201$ et 2142; [ $v_{1}\left(\mathrm{NO}_{3}\right), 1488 ; v_{5}\left(\mathrm{NO}_{3}{ }^{-}\right), 1313,36 v_{2}\left(\mathrm{NO}_{3}{ }^{-}\right)=1041$; $\left.\Delta v=175 \mathrm{~cm}^{-1}\right]$. Conductance $\wedge$ (S. $\left.\mathrm{cm}^{2} \cdot \mathrm{mol}^{-1}\right)=5$. eff $(\mathrm{MB})$ : 5.1 .

\subsection{Crystal Structure Determination}

Crystals suitable for single-crystal X-ray diffraction, of the reported compounds, were grown by slow evaporation of $\mathrm{MeOH}$ solution of the complexes. Details of the crystal structure solution and refinement are given in Table 1. Diffraction data were collected using an ENRAF NONIUS Kappa CCD diffractometer with graphite monochromatized MoK $\alpha$ radiation $(\lambda=0.71073 \AA)$. All data were corrected for Lorentz and polarization effects. No absorption correction was applied. Complex scattering factors were taken from the program package SHELXTL [25]. The structures were solved by direct methods, which revealed the position of all non-hydrogen atoms. All the structures were refined on $F^{2}$ by a full-matrix least-squares procedure using anisotropic displacement parameters for all non-hydrogen atoms [26]. The hydrogen atoms of water molecules and $\mathrm{NH}$ groups were located in the Fourier difference maps and refined. Others $\mathrm{H}$ atoms $\left(\mathrm{CH}\right.$ and $\mathrm{CH}_{3}$ groups) were geometrically optimized and refined as riding model by AFIX instructions. Molecular graphics were generated using ORTEP-3 [27].

\section{Results and Discussion}

\subsection{General Study}

The ligand $\quad \mathrm{H}_{2} \mathrm{~L} \quad$ 2-(-(2-(-2-hydroxy-3methoxybenzylideneamino)phenylimino)methyl)-6methoxyphenol was prepared by mixing under reflux ovanillin and 1,2-diamino benzene in molar ratio 2:1 in ethanol, following a reported method [24]. The $\mathrm{H}_{2} \mathrm{~L}$ react 
with $\mathrm{FeCl}_{2} \cdot 4 \mathrm{H}_{2} \mathrm{O}$ in methanol to yield $[\mathrm{Fe}(\mathrm{L})] \cdot \mathrm{H}_{2} \mathrm{O}$ (1). This metalloligand react with sodium thiocyanate in molar ratio $1: 3$ and the complex formulated as $\left[\left\{\mathrm{Fe}^{\mathrm{II}} \mathrm{Na}^{\mathrm{I}}(\mathrm{L})(\mathrm{EtOH})\left(\mathrm{HN}(\mathrm{CN})_{2}\right)\right\}(\quad-\mathrm{O})\left\{\mathrm{Fe}^{\mathrm{III}} \mathrm{Na}^{\mathrm{I}}(\mathrm{L})\left(\mathrm{NO}_{3}\right)\right\}\right]_{\mathrm{n}}$

(2) was afforded after slow evaporation of the filtrate. The IR spectrum of the metalloligand (1) shows an absorption band at $1627 \mathrm{~cm}^{-1}\left(1632 \mathrm{~cm}^{-1}\right.$ for the free $\left.\mathrm{H}_{2} \mathrm{~L}\right)$ which is indicative of a coordinated azomethine $(\mathrm{C}=\mathrm{N})$. Additional band $\quad(\mathrm{C}-$ $\mathrm{OPh})$ pointed at $1236 \mathrm{~cm}^{-1}$ correspond to the deprotonated phenoxy group. The corresponding band in the free ligand appears at $1254 \mathrm{~cm}^{-1}$ band. For the complex (2) the $(\mathrm{C}=\mathrm{N})$, $(\mathrm{C}-\mathrm{OPh})$ and $(\mathrm{C}-\mathrm{OMe})$ bands are pointed respectively at $1600 \mathrm{~cm}^{-1}, 1197 \mathrm{~cm}^{-1}$ and $1241 \mathrm{~cm}^{-1}$. The coordinated dicyanamide group exhibits band at $2250 \mathrm{~cm}^{-1}$, $2201 \mathrm{~cm}^{-1}$ and $2142 \mathrm{~cm}^{-1}$. The bands at $1488\left(v_{1}\right), 1313\left(v_{5}\right)$, $1041\left(v_{2}\right)$ and $v_{1}-v_{5}=175 \mathrm{~cm}^{-1}$ are indicative of the presence of a bidentate chelating nitrate group. The molar conductance $\Lambda^{\wedge}$ measured in DMF solution are 5 and $7 \mathrm{~S} \mathrm{~cm}^{2}$ $\mathrm{mol}^{-1}$ respectively for (1) and (2) which are indicative of a neutral electrolyte [28]. Magnetic moment at room temperature are $4.8 \quad$ в for (1) and $5.1 \quad$ в for (2). The magnetic moment value of (1) is close proximity of the spinonly value of $4.9 \quad$ в expected for a $\mathrm{d}^{6}$ iron(II) ion [29]. The magnetic moment for complex (2) is considerably smaller than the value of $10 \quad$ B expected for the simultaneous presence of one iron(II) and iron(III) ions. These results indicated that there are antiferromagnetic exchange interactions between the $\mathrm{d}^{6}$ iron(II) and $\mathrm{d}^{5}$ iron(III) ions present in the complex via the -oxo bridge [30].

\subsection{Crystal Structure}

The polymer formulated as $\left[\left\{\mathrm{Fe}^{\mathrm{II}} \mathrm{Na}^{\mathrm{I}}(\mathrm{L})(\mathrm{EtOH})\left(\mathrm{HN}(\mathrm{CN})_{2}\right)\right\}(-\mathrm{O})\left\{\mathrm{Fe}^{\mathrm{III}} \mathrm{Na}^{\mathrm{I}}(\mathrm{L})\left(\mathrm{NO}_{3}\right)\right\}\right]_{\mathrm{n}}$ (2) crystallizes in the triclinic system with a space group P-1. The crystal data collection and refinement are reported in Table 1. The ORTEP diagram of the structure of the heteronuclear polymer complex is illustrated in Figure 2. Selected bonds lengths and angles are listed in Table 2.

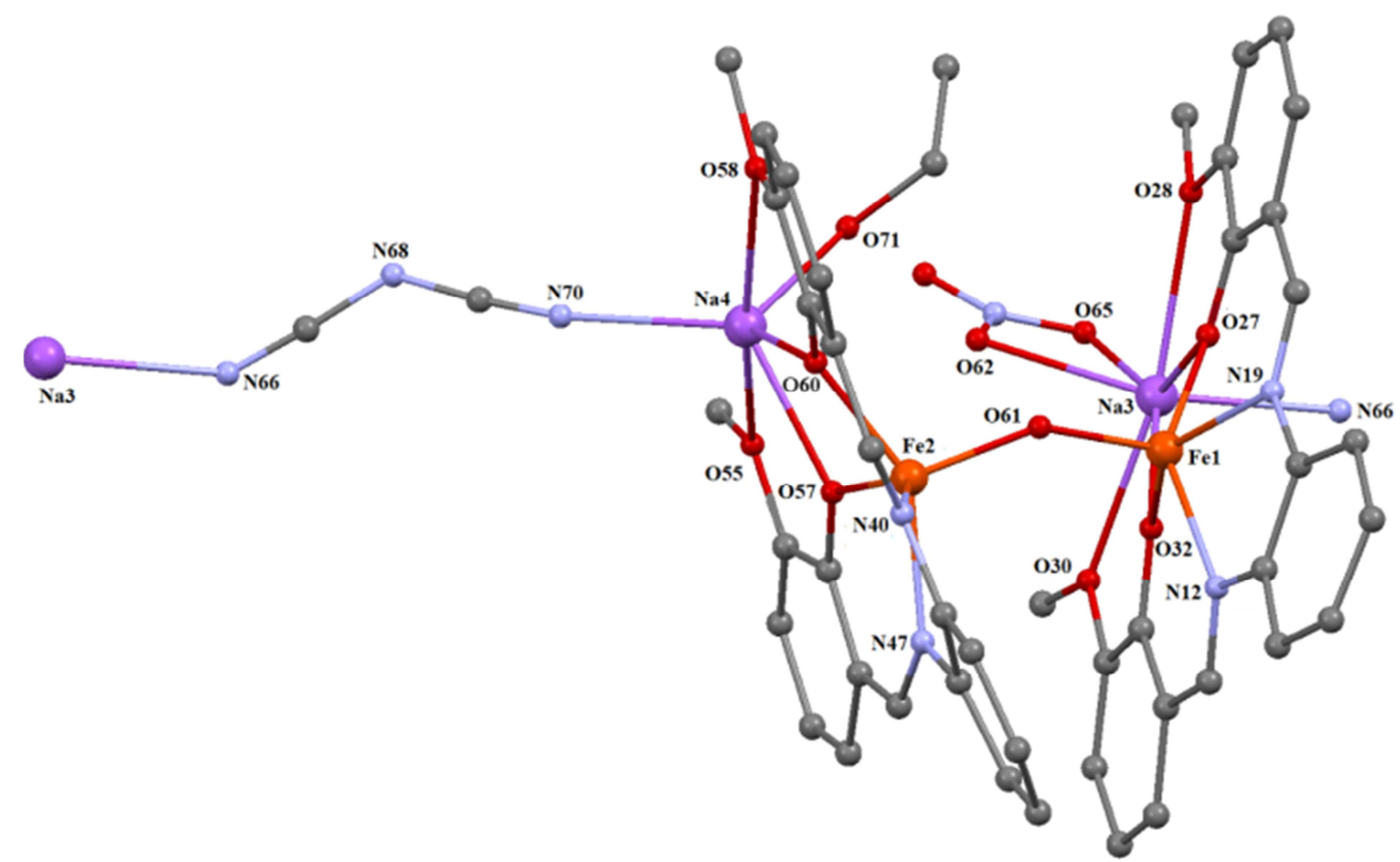

Figure 2. Crystal structure of the tetranuclear complex (2). H atoms are omitted for clarity. The labelling scheme of $C$ atoms in the ligand are not shown for clarity.

The oxo-bridged complex displays a structure constructed from two entities $\left[\mathrm{Fe}^{\mathrm{II}} \mathrm{Na}^{\mathrm{I}}(\mathrm{L})(\mathrm{EtOH})\left(\mathrm{HN}(\mathrm{CN})_{2}\right)\right]$ and $\left[\mathrm{Fe}^{\mathrm{III}} \mathrm{Na}^{\mathrm{I}}(\mathrm{L})\left(\mathrm{NO}_{3}\right)\right]$ bridged by an $\mathrm{O}^{2-}$ ion, giving rise to a heterotetranuclear neutral complex. These motifs are connected through the $\mathrm{Na}$ atoms to each other by protonated dicyanamide which acts as spacer via their two terminal nitrogen atoms. As shown in Figure 2, the asymmetric unit of the compound is made up of two dideprotonated chelating ligand molecule, two pentacoordinated iron atoms, one hexacoordinated sodium atom, one heptacoordinated $\mathrm{Na}$ atom, one bidentate nitrate group, one monodentate dicyanamide unit, one coordinated ethanol molecule and an $\mathrm{O}^{2-}$ ion. The twice deprotonated Schiff base molecule $\left(\mathrm{L}^{2-}\right)$ is a donor of $\mathrm{N}_{2} \mathrm{O}_{2} \mathrm{O}_{2}^{\prime}$. The arrangement of these atoms leads to the formation of one internal inner $\mathrm{N}_{2} \mathrm{O}_{2}$ and one outer inner $\mathrm{O}_{2} \mathrm{O}_{2}^{\prime}$. The iron ion atom being smaller than the sodium ion is located in the smaller cavity $\mathrm{N}_{2} \mathrm{O}_{2}$ and the sodium ion is located in the larger compartment $\mathrm{O}_{2} \mathrm{O}_{2}^{\prime}$ of the ligand. Each iron atom $(\mathrm{Fe} 1$ and $\mathrm{Fe} 2)$ atom is pentacoordinated in a $\mathrm{N}_{2} \mathrm{O}_{2}$ inner by two azomethine atoms and two phenolate oxygen 
atoms and are bridged by one dianionic oxygen atom $\left(\mathrm{O}^{2-}\right)$. The two sodium atoms are differently coordinated. The two sodium atoms of the complex $(\mathrm{Na} 3$ and $\mathrm{Na} 4)$ are situated in the $\mathrm{O}_{2} \mathrm{O}_{2}$ inner from the metalloligand (two phenolate oxygen atoms and two methoxy oxygen atoms). Additionally, two oxygen atoms from a bidentate nitrate moiety and one nitrogen atom (N66) from a dicyanamide group of another complex molecule coordinate the $\mathrm{Na} 3$ atom, resulting in a heptacoordinated $\mathrm{Na} 3$ atom. One nitrogen atom from a dicyanamide group and one oxygen atom from a coordinated ethanol molecule coordinated also the $\mathrm{Na} 4$ atom, resulting in a hexacoordinated sodium atom.

The environment around each pentacoordinated iron atom is determined using the Addison [31] parameter $(\tau)$ which is calculated with the following formula $\tau=(\beta-\alpha) / 60$ (where $\alpha$ and $\beta$ are the values of the largest bond angles around the iron atom). When $\tau=0$, the geometry is a pyramid with a perfect square base; $\tau=1$ indicates a perfect trigonal bipyramid geometry. The trigonality indices $\tau$ values of the $\mathrm{Fe} 1$ and the Fe2 are respectively 0.013 and 0.029 . These values are indicative of a slightly distorted square pyramidal around each iron atom. The distortion is greater around $\mathrm{Fe} 2$ atom. For $\mathrm{Fe} 1$ and $\mathrm{Fe} 2$ atoms, the basal planes are defined by the atoms [N12, N19, O27, O32] for Fe1 and [O60, O57, N40, N47] for Fe2. The two pyramids share one vertex occupied by the oxygen atom $\mathrm{O} 61$ that is on the axial positions of the two square pyramids (Figure 3). The Fe1Fe2 distance is 3.3998(5) $\AA$.

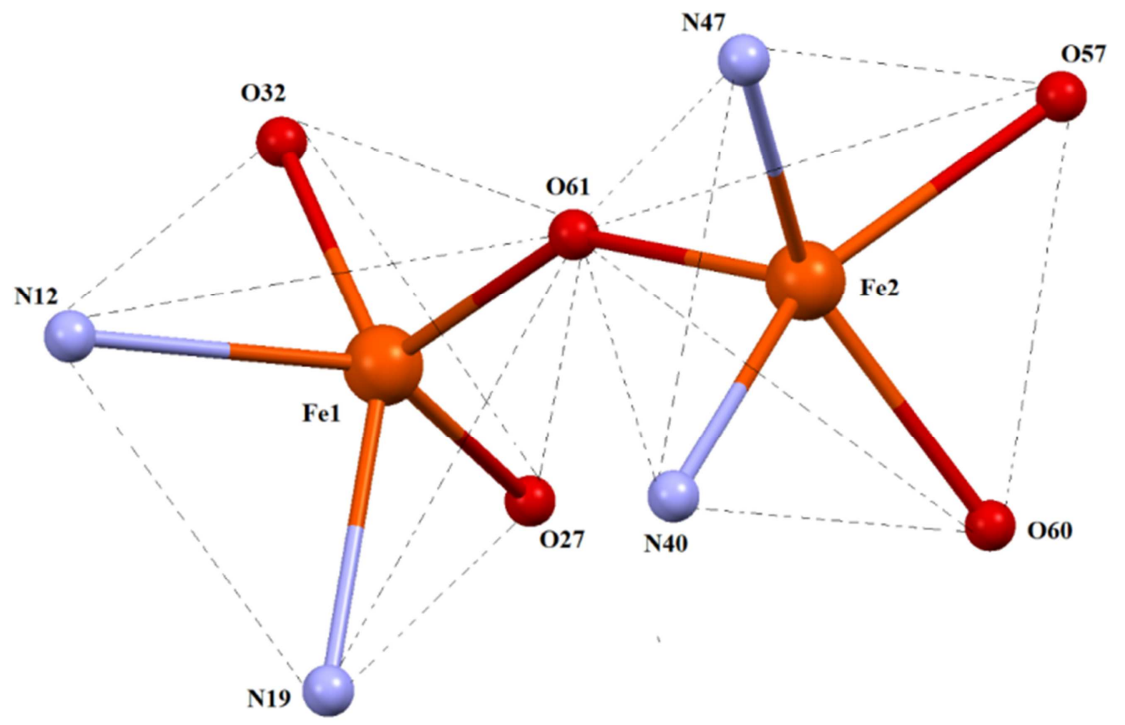

Figure 3. Plot showing the coordination sphere of the two iron atoms in the crystal.

Table 1. Crystal data, X-ray data collection, data reduction and structure refinement for (2).

\begin{tabular}{|c|c|}
\hline \multicolumn{2}{|l|}{ Crystal data } \\
\hline Chemical formula & $\mathrm{C}_{48} \mathrm{H}_{43} \mathrm{Fe}_{2} \mathrm{~N}_{8} \mathrm{Na}_{2} \mathrm{O}_{13}$ \\
\hline$M_{\mathrm{r}}$ & 1088.59 \\
\hline Crystal system, space group & Triclinic, $P-1$ \\
\hline Temperature $(\mathrm{K})$ & 293 \\
\hline$a, b, c(\AA)$ & $13.39754(16), 13.98896(16), 14.2041$ (3) \\
\hline$, \quad, \quad\left({ }^{\circ}\right)$ & $74.4737(15) ; 67.6043(15) ; 72.7787(10)$ \\
\hline$V\left(\AA^{3}\right)$ & $2314.53(7)$ \\
\hline$Z$ & 2 \\
\hline Calculated density $\left(\mathrm{g} \cdot \mathrm{cm}^{-3}\right)$ & 1.562 \\
\hline$F(000)$ & 1120 \\
\hline Radiation type & $=0.71073 \AA$ \\
\hline$\mu\left(\mathrm{mm}^{-1}\right)$ & 0.72 \\
\hline Crystal size (mm) & $0.32 \times 0.09 \times 0.08$ \\
\hline \multicolumn{2}{|l|}{ Data collection } \\
\hline Diffractometer & XtaLAB AFC12 (RCD3): Kappa single \\
\hline Absorption correction & Multi-scan \\
\hline$T_{\min } . T_{\max }$ & $0.893 ; 1.000$ \\
\hline \multicolumn{2}{|l|}{ Limiting indices } \\
\hline $\mathrm{h}$ & $-19 \rightarrow 18$ \\
\hline $\mathrm{k}$ & $-20 \rightarrow 20$ \\
\hline 1 & $-20 \rightarrow 20$ \\
\hline No. of measured, independent and observed $[I>2 \sigma(I)]$ reflections & $57221,13219,11414$ \\
\hline$R_{\text {int }}$ & 0.030 \\
\hline \multicolumn{2}{|l|}{ Refinement } \\
\hline$R\left[F^{2}>2 \sigma\left(F^{2}\right)\right], w R\left(F^{2}\right), S$ & $0.044,0.128,1.06$ \\
\hline
\end{tabular}




\begin{tabular}{ll}
\hline Crystal data & \\
\hline No. of reflections & 13219 \\
No. of parameters/restraints & $667 / 3$ \\
$\mathrm{H}$-atom treatment & $\mathrm{H}$ atoms treated by a mixture of independent and constrained refinement \\
$\Delta \rho_{\max } \Delta \rho_{\min }\left(\mathrm{e} \AA^{-3}\right)$ & $0.97 \&-1.54$ \\
\hline
\end{tabular}

Table 2. Selected bond lengths [A] and angles $\left(^{\circ}\right)$ for the complex 2.

\begin{tabular}{|c|c|c|c|}
\hline Bond & bond lengths $[\AA ̊]$ & Bond & bond angles $\left({ }^{\circ}\right)$ \\
\hline $\mathrm{Fe} 1-\mathrm{O} 32$ & $1.9164(13)$ & $\mathrm{O} 32-\mathrm{Fe} 1-\mathrm{O} 27$ & $84.79(6)$ \\
\hline $\mathrm{Fe} 1-\mathrm{O} 27$ & $1.9249(13)$ & $\mathrm{O} 32-\mathrm{Fe} 1-\mathrm{N} 19$ & $144.23(6)$ \\
\hline $\mathrm{Fe} 1-\mathrm{O} 61$ & $1.7813(14)$ & $\mathrm{O} 32-\mathrm{Fe} 1-\mathrm{N} 12$ & $87.95(6)$ \\
\hline $\mathrm{Fe} 1-\mathrm{N} 19$ & $2.0891(15)$ & $\mathrm{O} 27-\mathrm{Fe} 1-\mathrm{N} 19$ & $87.15(6)$ \\
\hline $\mathrm{Fe} 1-\mathrm{N} 12$ & $2.0790(15)$ & $\mathrm{O} 27-\mathrm{Fe} 1-\mathrm{N} 12$ & $143.46(6)$ \\
\hline $\mathrm{Na} 3-\mathrm{O} 27$ & $2.4307(15)$ & $\mathrm{N} 12-\mathrm{Fe} 1-\mathrm{N} 19$ & $78.18(6)$ \\
\hline $\mathrm{Na} 3-\mathrm{O} 28$ & $2.6470(17)$ & $\mathrm{O} 32-\mathrm{Na} 3-\mathrm{O} 27$ & $84.79(5)^{\circ}$ \\
\hline $\mathrm{Fe} 2-\mathrm{O} 57$ & $1.9200(13)$ & $\mathrm{O} 27-\mathrm{Na} 3-\mathrm{N} 66^{\mathrm{i}}$ & $93.81(6)^{\circ}$ \\
\hline $\mathrm{Fe} 2-\mathrm{O} 60$ & 1.9254 (13) & $\mathrm{O} 32-\mathrm{Na} 3-\mathrm{N} 66^{\mathrm{i}}$ & $101.78(7)^{\circ}$ \\
\hline $\mathrm{Fe} 2-\mathrm{O} 61$ & $1.7856(13)$ & $\mathrm{Fe} 1-\mathrm{O} 61-\mathrm{Fe} 2$ & $144.78(8)^{\circ}$ \\
\hline $\mathrm{Fe} 2-\mathrm{N} 40$ & $2.0989(15)$ & $\mathrm{O} 57-\mathrm{Fe} 2-\mathrm{O} 60$ & $85.50(6)$ \\
\hline $\mathrm{Fe} 2-\mathrm{N} 47$ & $2.0855(16)$ & $\mathrm{O} 57-\mathrm{Fe} 2-\mathrm{N} 40$ & $142.60(6)$ \\
\hline $\mathrm{Na} 4-\mathrm{O} 55$ & $2.6007(18)$ & $\mathrm{N} 47-\mathrm{Fe} 2-\mathrm{N} 40$ & $77.46(6)$ \\
\hline $\mathrm{Na} 4-\mathrm{O} 57$ & $2.3849(16)$ & $\mathrm{O} 60-\mathrm{Fe} 2-\mathrm{N} 40$ & $87.75(6)$ \\
\hline $\mathrm{Na} 3-\mathrm{O} 30$ & $2.5662(17)$ & $\mathrm{O} 60-\mathrm{Fe} 2-\mathrm{N} 47$ & $144.32(6)$ \\
\hline $\mathrm{Na} 3-\mathrm{O} 32$ & $2.4133(15)$ & $\mathrm{O} 57-\mathrm{Fe} 2-\mathrm{N} 47$ & $86.99(6)$ \\
\hline $\mathrm{Na} 3-\mathrm{O} 62$ & $2.4435(18)$ & $\mathrm{O} 60-\mathrm{Na} 4-\mathrm{O} 57$ & $66.52(5)^{\circ}$ \\
\hline $\mathrm{Na} 3-\mathrm{O} 65$ & $2.5402(19)$ & $\mathrm{N} 70-\mathrm{Na} 4-\mathrm{O} 57$ & $120.85(8)^{\circ}$ \\
\hline $\mathrm{Na} 3-\mathrm{N} 66^{\mathrm{i}}$ & $2.453(2)$ & $\mathrm{N} 70-\mathrm{Na} 4-\mathrm{O} 60$ & $121.54(8)^{\circ}$ \\
\hline $\mathrm{Na} 4-\mathrm{O} 58$ & $2.7189(18)$ & & \\
\hline $\mathrm{Na} 4-\mathrm{O} 60$ & $2.3746(16)$ & & \\
\hline $\mathrm{Na} 4-\mathrm{O} 71$ & $2.280(2)$ & & \\
\hline $\mathrm{Na} 4-\mathrm{N} 70$ & $2.372(2)$ & & \\
\hline
\end{tabular}

Symmetry Codes: (i) $x, y, z-1$.

The mean bond distance $\mathrm{Fe}-\mathrm{N}$ of $2.0882 \AA$ is comparable to the distances found for the complexes [( $\mathrm{O})\{\mathrm{Fe}$ (vanophen $\left.)\}_{2}\right] \cdot 2 \mathrm{H}_{2} \mathrm{O} \quad\left(\mathrm{H}_{2}\right.$ vanophen is $\quad\left(N, N^{\prime}-(1,2-\right.$ phenylene)-bis(3-methoxysalicylideneimine)) and [( O) $\left.\{\mathrm{Fe} \text { (naphophen) }\}_{2}\right] \cdot 2 \mathrm{CH}_{2} \mathrm{Cl}_{2}\left(\mathrm{H}_{2}\right.$ naphophen is $(\mathrm{N}, \mathrm{N}$ '-bis $(2-$ hydroxy-1-naphthaldehyde)-1,2-phenylenediimine)) [32]. The mean bond distance $\mathrm{Fe}-\mathrm{O}$ (phenoxo) is $1.9250 \AA$, which is shorter than the mean bond distance $\mathrm{Fe}-\mathrm{O}$ (bridge) of $1.7835 \AA$. These values are comparable to those reported for the complex $[\mathrm{Fe}(\mathrm{TPC})]_{2} \mathrm{O}$ (TPC is 7,8-dihydro-5,10,15,20tetraphenylporphyrinato) [33]. The $\mathrm{Fe} 1-\mathrm{O} 61-\mathrm{Fe} 2$ angle is $143.78(9)^{\circ}$. For both iron atoms, the values of the transoid angles are in the range $\left[143.46(6)^{\circ}-144.23(6)^{\circ}\right]$ while the cissoid angle values are in the range $\left[77.46(6)^{\circ}-87.95(6)^{\circ}\right.$ ]. These values are different from the ideal angles for a perfect square pyramid. The values of the $\mathrm{Fe}-\mathrm{O}-\mathrm{Na}$ angles in this polymer are comparable with the following values: $\mathrm{Fe} 1-$ $\mathrm{O} 27-\mathrm{Na} 3=103.38$ (6); $\mathrm{Fe} 1-\mathrm{O} 32-\mathrm{Na} 3=104.28$ (6); $\mathrm{Fe} 2-\mathrm{O} 60-\mathrm{Na} 4=101.94(6) ; \mathrm{Fe} 2-\mathrm{O} 57-\mathrm{Na} 4=101.74$ (6). In the basal planes of the square pyramidal, the Fe$\mathrm{O}_{\text {phenolate }}$ distances are the smallest and lie in the range [1.9164 (13) -1.9254 (13) $\AA$ ] while the $\mathrm{Fe}-\mathrm{N}_{\text {imino }}$ bond distances are the longest $[2.0790$ (15) -2.0989 (15) $\AA]$. These values are close to those reported in a heteronuclear complex formulated as $\left[\mathrm{NaFe}_{6}(\mathrm{sae})_{6}(\mathrm{MeO})_{6}\right] \cdot\left(\mathrm{N}(\mathrm{CN})_{2}\right) \cdot\left(\mathrm{H}_{2} \mathrm{O}\right)$
[34] where the Schiff-based ligand $\mathrm{H}_{2}$ sae is salicylidene-2ethanolamine. The $\mathrm{Na}-\mathrm{O}_{\text {methoxy }}$ bond distances are the longest in the structure [2.5662 (17) $-2.7189(18) \AA]$.

Each organic ligand hosts one sodium (I) ion in its $\mathrm{O}_{2} \mathrm{O}_{2}$ open site and one iron atom in the adjacent $\mathrm{N}_{2} \mathrm{O}_{2}$ iminic inner. The two ions, in close proximity to each other $(\mathrm{Fe} 1 \cdots \mathrm{Na} 3=$ $3.432 \AA, \mathrm{Fe} 2 \cdots \mathrm{Na} 4=3.352 \AA$ ), share two bridging phenolate oxygen atoms of the organic ligand. The $\mathrm{Na} 4$ ion exhibits a distorted 6-fold coordination, involving four $\mathrm{O}$ atoms of the organic ligand, one additional coordinated $\mathrm{C}_{2} \mathrm{H}_{5} \mathrm{OH}$ molecule and one nitrogen atom of the dicyanamide group. The $\mathrm{Na} 3$ ion has a 7-fold coordination involving four $\mathrm{O}$ atoms of the organic ligand, two $\mathrm{O}$ atoms from a bidentate chelating nitrate groups and one nitrogen atom of the dicyanamide group of another molecule.

The environment around the 6-fold sodium atom $\mathrm{Na} 4$ can be described as a distorted pyramidal pentagon while the geometry of the 7-fold sodium atom $\mathrm{Na} 3$ is best described as a distorted bipyramid pentagon (Figure 4). The basal angles for both geometries are in the range $\left[60-90^{\circ}\right]$. These values deviate from the value of the ideal angle for a regular pentagon $\left(72^{\circ}\right)$ and the sum of the equatorial angles around $\mathrm{Na} 3$ and $\mathrm{Na} 4$ are respectively $358.15^{\circ}$ and $355.86^{\circ}$. The apical position for the pentagon pyramid around $\mathrm{Na} 4$ is occupied by N70. N66 and O62 occupy the axial positions 
for the severely distorted pentagonal bipyramid geometry around $\mathrm{Na} 3$ with the angle value of $145.62(7)^{\circ}$.

The hydrogen bonding geometry of the compound is listed in Table 3. Intermolecular hydrogen bond $\mathrm{C} 45-\mathrm{H} 45 \ldots \mathrm{O} 65^{\mathrm{i}}$, $\mathrm{C} 24-\mathrm{H} 24 \ldots \mathrm{O} 68^{\mathrm{ii}}$ and intramolecular hydrogen bond $\mathrm{C} 29-$ H29C...O65, O71-H71...O62 has been observed. In crystal,
$\mathrm{C}-\mathrm{H} . . \mathrm{O}$ and $\mathrm{O}-\mathrm{H} . . \mathrm{O}$ hydrogen bonds link the molecules. The structure consists of several chains superimposed on each other. These chains are linked by inter and intramolecular bonds which ensure the cohesion and stability of the polymer as shown in Figure 5.

Table 3. Hydrogen-bond geometry ( $A$, $\left.{ }^{\circ}\right)$.

\begin{tabular}{|c|c|c|c|c|}
\hline$D-\mathbf{H} \cdots A$ & $D-\mathbf{H}$ & $\mathrm{H} \cdots A$ & $D \cdots A$ & $D-\mathbf{H} \cdots A$ \\
\hline $\mathrm{C} 45-\mathrm{H} 45 \cdots \mathrm{O} 65^{\mathrm{i}}$ & 0.93 & 2.49 & $3.067(3)$ & 119.9 \\
\hline $\mathrm{O} 71-\mathrm{H} 71 \cdots \mathrm{O} 62$ & $0.871(9)$ & $1.96(2)$ & $2.761(3)$ & $152(3)$ \\
\hline $\mathrm{C} 24-\mathrm{H} 24 \cdots \mathrm{N} 68^{\mathrm{ii}}$ & 0.93 & 2.49 & $3.392(3)$ & 164.5 \\
\hline $\mathrm{C} 29-\mathrm{H} 29 \mathrm{C} \cdots \mathrm{O} 65$ & 0.96 & 2.64 & $3.416(4)$ & 138.1 \\
\hline
\end{tabular}

Symmetry codes: (i) $x+1, y, z$; (ii) $-x,-y+2,-z+1$.
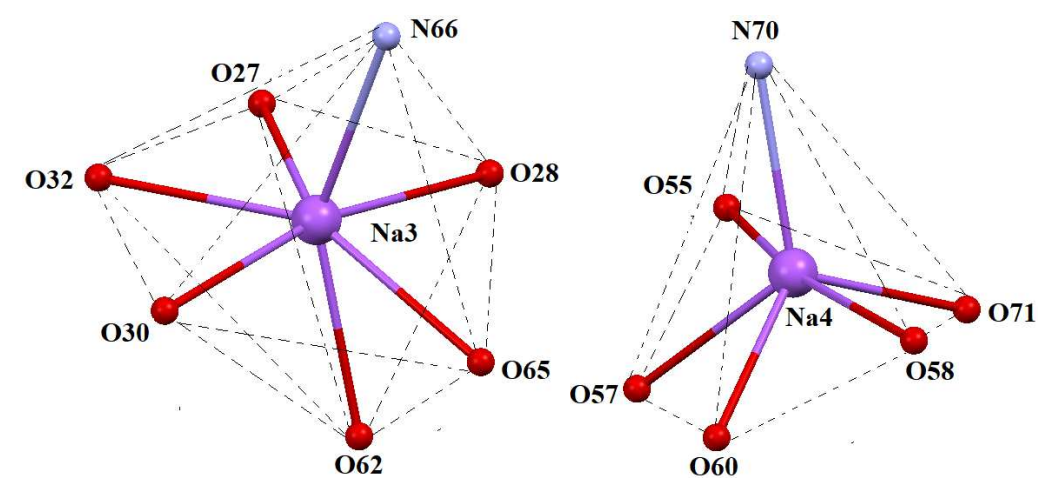

Figure 4. Plot showing the coordination sphere of the two sodium ions in the crystal.

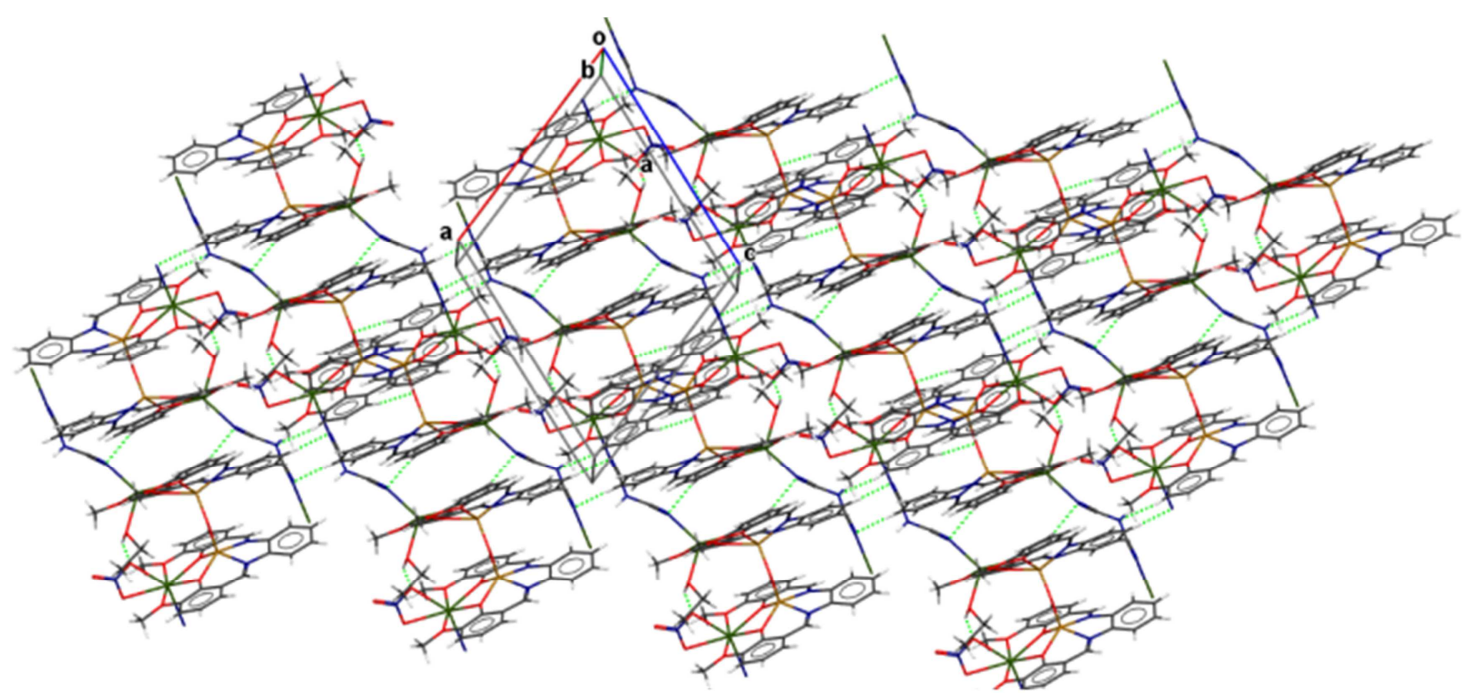

Figure 5. Crystal packing observed in the complex.

\section{Conclusion}

In summary, we have successfully synthesized and studied the hetero tetranuclear complex containing two natrium (I), one iron (II) and iron (III) ions. A suitable crystal of the complex was obtained by slow evaporation of ethanol solution of the compound for two weeks. Infrared spectra of the compound and the metalloligand were discussed in this paper. Crystal data, X-ray data collection, data reduction and structure refinement are studied. The heteronuclear complex crystallizes in the triclinic system with a space group P-1.
The two square pyramidal environments of the iron (II) and iron (III) ions share one vertex. The environment around the 6-fold sodium atom $\mathrm{Na} 4$ can be described as a distorted pyramidal pentagon while the geometry of the 7-fold sodium atom $\mathrm{Na} 3$ is best described as a distorted bipyramidal pentagon.

\section{Supplementary Materials}

CCDC-1978558 contains the supplementary crystallographic data for this paper. These data can be 
obtained free of charge from the Cambridge Crystallographic data Center via www.ccdc.cam.ac.uk/data_request/cif.

\section{Conflicts of Interest}

The authors declare that they have no competing interests.

\section{Acknowledgements}

The authors thank the FONDATION SONATEL for his financial support. http://fondationsonatel.sn/.

\section{References}

[1] N. Mahlooji, M. Behzad, H. A. Rudbari, G. Bruno and B. Ghanbari, Unique Examples of Copper(II)/Sodium(I) and Nickel(II)/Sodium(I) Schiff Base Complexes with Bridging Bis-Bidentate Salen Type Ligand: Synthesis, Crystal Structures and Antibacterial Studies. Inorganica Chimica Acta (2016), 445, 124-128.

[2] M. Sarr, E. I. Thiam, M. Gaye, A. H. Barry, N. Alvarez and J. Ellena, Co-Crystal Structure of a Dinuclear $(\mathrm{Zn}-\mathrm{Y})$ and a Trinuclear (Zn-Y-Zn) Complexes Derived from a Schiff Base Ligand. European Journal of Chemistry (2018), 9, 67-73.

[3] M. Sarr, M. Diop, E. I. Thiam, M. Gaye, A. H. Barry, J. B. Orton and S. J. Coles, A New Co-Crystal Dinuclear/Trinuclear $\mathrm{Zn}^{\mathrm{II}}-\mathrm{Zn}^{\mathrm{II}} / \mathrm{Zn}^{\mathrm{II}}-\mathrm{Sm}^{\mathrm{III}}-\mathrm{Zn}^{\mathrm{II}} \quad$ Complex with a Salen-Type Schiff Base Ligand. Acta Crystallographica E (2018), 74, 1862-1866.

[4] J.-P. Costes, F. Dahan, L. Vendier, S. Shova, G. Lorusso and M. Evangelisti, $\mathrm{Ni}^{\mathrm{II}}-\mathrm{Ln}^{\mathrm{III}}$ Complexes with o-Vanillin as the Main Ligand: Syntheses, Structures, Magnetic and Magnetocaloric Properties. Dalton Transactions (2018), 47, $1106-1116$.

[5] M. Mousavi, V. Béreau, J.-P. Costes, C. Duhayon and J.-P. Sutter, Oligomeric and Polymeric Organizations of Potassium Salts with Compartmental Schiff-Base Complexes as Ligands. CrystEngComm (2011), 13, 5908-5914.

[6] T. Fatima, Imtiaz-ud-Din, A. Akbar, M. S. Anwar and M. N. Tahir, Six New Dinuclear Schiff Base Complexes of $\mathrm{Cu}(\mathrm{II}) / \mathrm{Ln}(\mathrm{III})$ System: Synthesis, Characterization and Magnetic Studies. Journal of Molecular Structure (2019), $1184,462-467$.

[7] B. Cristóvão, D. Osypiuk, B. Miroslaw and Bartyzel, A. Syntheses, Crystal Structures, Thermal and Magnetic Properties of New Heterotrinuclear $\mathrm{Cu}^{\mathrm{II}}-\mathrm{Ln}^{\mathrm{III}}-\mathrm{Cu}^{\mathrm{II}}$ Complexes Incorporating $\mathrm{N}_{2} \mathrm{O}_{4}$-Donor Schiff Base Ligands. Polyhedron (2018), 144, 225-233.

[8] L. Zhang, P.-P. Yang, L.-F. Li, Y.-Y. Hu and X.-L. Mei, A Tridecanuclear $\mathrm{ZnGd}_{12}$ Nanoscopic Cluster Exhibiting Large Magnetocaloric Effect. Inorganica Chimica Acta (2019), 499, 119170 .

[9] B. Monteiro, J. T. Coutinho and L. C. J. Pereira, Heterometallic 3d-4f SMMs. In Lanthanide-Based Multifunctional Materials; Elsevier, 2018; 1st Edition, pp 233-261.

[10] S. Zhao, X. Lü, A. Hou, W.-Y. Wong, W.-K. Wong, X. Yang and R. A. Jones, Heteronuclear Trimetallic and 1D Polymeric 3d-4f Schiff Base Complexes with $\mathrm{OCN}^{-}$and $\mathrm{SCN}^{-}$Ligands. Dalton Transactions (2009), 43, 9595-9602.

[11] W.-K. Dong, S.-S. Zheng, J.-T. Zhang, Y. Zhang and Y.-X. Sun, Luminescent Properties of Heterotrinuclear $3 \mathrm{~d}-4 \mathrm{f}$ Complexes Constructed from a Naphthalenediol-Based Acyclic Bis(Salamo)-Type Ligand. Spectrochimica Acta, Part A: Molecular and Biomolecular Spectroscopy (2017), 184, 141-150.

[12] J.-W. Zhang, W.-H. Liu, C.-R. Wang, B.-Q. Liu and Y.-P. Dong, A Series of Linear $\mathrm{Co}_{2}{ }_{2} \mathrm{Ln}^{\mathrm{III}}{ }_{2}$ Clusters Derived from 3,4-Dichlorobenzoate and 2,2'-Bipyridine: Syntheses, Structures, and Properties. Inorganica Chimica Acta (2020), 502,119343 .

[13] M. T. Kaczmarek, M. Zabiszak, M. Nowak and R. Jastrzab, Lanthanides: Schiff Base Complexes, Applications in Cancer Diagnosis, Therapy, and Antibacterial Activity. Coordination Chemistry Reviews (2018), 370, 42-54.

[14] B. Cristóvão, B. Miroslaw, J. Kłak and M. Rams, CarbonatoBridged Heteronuclear $\mathrm{Ni}_{2}{ }_{2} \mathrm{Ln}^{\mathrm{III}}{ }_{2}(\mathrm{Ln}=\mathrm{Tb}, \mathrm{Dy}, \mathrm{Ho}, \mathrm{Er}, \mathrm{Tm}$, $\mathrm{Yb}, \mathrm{Lu}$ ) Complexes Synthesized by Fixation of Atmospheric $\mathrm{CO}_{2}-$ Structural and Magnetic Studies. Polyhedron (2015), 85, 697-704.

[15] A. Bilyachenko, M. Levitsky, A. Yalymov, A. Korlyukov, A. Vologzhanina, Y. Kozlov, L. Shulpina, D. Nesterov, A. Pombeiro, F. Lamaty, X. Bantreil, A. Fetre, D. Liu, J. Martinez, J. Long, J. Larionova, Y. Guari, A. L. Trigub, Y. V. Zubavichus, I. E. Golub, O. A. Filippov, E. S. Shubina, and G. B. Shul'pin, A Heterometallic $\left(\mathrm{Fe}_{6} \mathrm{Na}_{8}\right)$ Cage-like Silsesquioxane: Synthesis, Structure, Spin Glass Behavior and High Catalytic Activity. RSC Advances (2016), 6, 48165-48180.

[16] S. Hou, X.-Y. Tang, Y. Li, R.-X. Wang, F.-F. Chen, Y. Wang, Y.-X. Chi and J. Jin, Syntheses, Crystal Structures and Photophysical Properties of a Series of Zn-Ln Coordination Polymers. Journal of Molecular Structure (2018), 1167, 239-247.

[17] P.-P. Liu, C.-Y. Wang, M. Zhang and X.-Q. Song, Pentanuclear Sandwich-Type $\mathrm{Zn}^{\text {II }}-\mathrm{Ln}^{\text {III }}$ Clusters Based on a New Salen-like Salicylamide Ligand: Structure, near-Infrared Emission and Magnetic Properties. Polyhedron (2017), 129, 133-140.

[18] M. Maity, M. C. Majee, S. Kundu, S. K. Samanta, E. C. Sañudo, S. Ghosh and M. Chaudhury, Pentanuclear 3d-4f Heterometal Complexes of $\mathrm{M}_{3}^{\mathrm{II}} \mathrm{Ln}^{\mathrm{III}}{ }_{2}(\mathrm{M}=\mathrm{Ni}, \mathrm{Cu}, \mathrm{Zn}$ and $\mathrm{Ln}$ $=\mathrm{Nd}, \mathrm{Gd}, \mathrm{Tb})$ Combinations: Syntheses, Structures, Magnetism, and Photoluminescence Properties. Inorganic Chemistry (2015), 54 (20), 9715-9726.

[19] W.-X. Feng, Y.-N. Hui, G.-X. Shi, D. Zou, X.-Q. Lü, J.-R. Song, D.-D. Fan, W.-K. Wong and R. A. Jones, Synthesis, Structure and near-Infrared (NIR) Luminescence of Series of $\mathrm{Zn}_{2} \mathrm{Ln}(\mathrm{Ln}=\mathrm{Nd}, \mathrm{Yb}$ or Er) Complexes Based on the SalenType Schiff-Base Ligand with the Flexible Linker. Inorganic Chemistry Communications (2012), 20, 33-36.

[20] Y. Chen, S. She, L. Zheng, B. Hu, W. Chen, B. Xu, Z. Chen, F. Zhou and Y. Li, Heteronuclear M(II)-Ln(III) $(\mathrm{M}=\mathrm{Co}, \mathrm{Mn}$; $\mathrm{Ln}=\mathrm{La}, \mathrm{Pr}, \mathrm{Sm}, \mathrm{Gd}$, Dy and Er) Coordination Polymers: Synthesis, Structures and Magnetic Properties. Polyhedron (2011), 30, 3010-3016.

[21] D. Pinkert, S. Demeshko, F. Schax, B. Braun, F. Meyer and C. A Limberg, Dinuclear Molecular Iron(II) Silicate with Two High-Spin Square-Planar $\mathrm{FeO}_{4}$ Units. Angewandte Chemie International Edition (2013), 52, 5155-5158. 
[22] K. Mason, I. A. Gass, S. Parsons, A. Collins, F. J. White, A. M. Z. Slawin, E. K. Brechin and P. A. Tasker, Building Fe(Iii) Clusters with Derivatised Salicylaldoximes. Dalton Transactions (2010), 39, 2727-2734.

[23] A. Dogaru, J.-L. Liu, C. Maxim, G. Marinescu, R. Clérac and M. Andruh, Assembling $\mathrm{Cu}^{\mathrm{II}} \mathrm{Ln}^{\mathrm{III}} \mathrm{Os}^{\mathrm{III}}$ Heterotrimetallic Octanuclear Complexes and 1D Coordination Polymers from the Same Molecular Modules. Polyhedron (2020), 175, 114242 .

[24] S. Thakurta, J. Chakraborty, G. Rosair, R. J. Butcher and Mitra, S. The Interplay of $\mathrm{O}-\mathrm{H} \cdot \cdots \mathrm{O}$ Hydrogen Bonding in the Generation of Three New Supramolecular Complexes of CuII, $\mathrm{Ni}^{\mathrm{II}}$ and $\mathrm{Co}^{\mathrm{III}}$ : Syntheses, Characterization and Structural Aspects. Inorganica Chimica Acta (2009), 362, 2828-2836.

[25] G. M. Sheldrick, It SHELXT - Integrated Space-Group and Crystal-Structure Determination. Acta Crystallographica A (2015), 71, 3-8.

[26] G. M. Sheldrick, Crystal Structure Refinement with It SHELXL. Acta Crystallographica C (2015), 71, 3-8.

[27] L. J. Farrugia, It WinGX and It ORTEP for Windows: An Update. Journal of Applied Crystallography (2012), 45, 849854.

[28] W. J. Geary, The Use of Conductivity Measurements in Organic Solvents for the Characterisation of Coordination Compounds. Coordination Chemistry Reviews (1971), 7, 81122.

[29] R. D. Bereman, M. L. Good, B. J. Kalbacher and J. Buttone, Preparation, Characterization, Moessbauer Spectra, and Electron Spin Resonance Spectra of Iron(II) and Iron(III) Complexes of the Dithiolate
Cyclopentadienedithiocarboxylate. Inorganic Chemistry (1976), 15, 618-621.

[30] S.; Ross, T. Weyhermüller, E. Bill, E. Bothe, U. Flörke, K. Wieghardt and P. Chaudhuri, Asymmetric Heterodinuclear $\mathrm{Fe}^{\mathrm{III}} \mathrm{M}^{\mathrm{II}}(\mathrm{M}=\mathrm{Zn}, \mathrm{Cu}, \mathrm{Ni}, \mathrm{Fe}, \mathrm{Mn}), \mathrm{Co}^{\mathrm{III}} \mathrm{Fe}^{\mathrm{II}}$ and $\mathrm{Fe}^{\mathrm{II}} \mathrm{Co}^{\mathrm{III}}$ Species: Synthesis, Structure, Redox Behavior, and Magnetism. European Journal of Inorganic Chemistry (2004), 984-997.

[31] A. W. Addison, T. N. Rao, J. Reedijk, J. van Rijn and G. C. Verschoor, Synthesis, Structure, and Spectroscopic Properties of Copper(II) Compounds Containing Nitrogen-Sulphur Donor Ligands; the Crystal and Molecular Structure of Aqua[1,7-Bis(N-Methylbenzimidazol-2'-yl)-2,6-Dithiaheptane] Copper(II) Perchlorate. Journal of Chemical Society Dalton Transactions (1984), 1349-1356.

[32] S. Jana, S. Chatterjee and S. Chattopadhyay, Syntheses, Characterization and X-Ray Crystal Structures of HexaCoordinated Monomeric and Oxo-Bridged Dimeric Fe(III) Compounds with Salen-Type Schiff Bases. Polyhedron (2012), 48, 189-198.

[33] S. H. Strauss, M. J. Pawlik, J. Skowyra, J. R. Kennedy, O. P. Anderson, K. Spartalian and J. L. Dye, Comparison of the Molecular and Electronic Structures of $(\mu-$ Oxo)bis[(5,10,15,20-Tetraphenylporphyrinato)Iron(III) $]$ and ( $\mu$-Oxo)bis[(7,8-Dihydro-5,10,15,20-

Tetraphenylporphyrinato)Iron(III)]. Inorganic Chemistry (1987), 26, 724-730.

[34] Y. Li, Q. Wu, L. Lecren and R. Clérac, Synthesis, Structure and Magnetism of New Polynuclear Transition Metal Aggregates Assembled with Schiff-Base Ligand and Anionic N-Donor Ligands. Journal of Molecular Structure (2008), 890, 339-345. 